\title{
IMPROVING THE QUALITY AND QUANTITY OF PRODUCTION ${ }^{1}$
}

\author{
BY THOMAS G. WRIGHT ${ }^{2}$
}

Mr. John R. Hinman, President of the International Paper Company, made the following statements in his annual report for 1953: "There is no reason for a shortage of wood as long as our companies and our industry continue to face and to solve the two basic questions in the whole forest problem - how to increase growth and how to utilize everything that is grown on our forest acres. I do not doubt that this continent's forest acres can grow twice the volume of wood they now grow".

Mr. Walter DeLong, Vice-President of the Weyerhauser Timber Company, writes in the Weyerhauser News that, next to the number one objective of operating a profitable business, the second management objective of his company is "to get the maximum growth of wood from every acre of our Tree Farms".

Maximum volume of wood production is, then, a stated objective of these two large companies. It is basic statement of policy with which I believe most foresters would agree.

Just how are we to attain this objective here on the Coastal region of British Columbia, and what are our major problems?

In my view, the two aspects of greater quantity production which should be given increased attention are first, the problem of restocking our better sites; and second, the problem of hardwood invasion. These problems are closely related to each other.

It is commonly recognized that our good sites present the most serious regeneration problem. I have noticed particularly that after the first crop of second growth is cut here on the Coast there is a tendency for the brush to take over. One acre of Site II is equivalent to five acres of Site V, and the poor sites tend to take care of themselves. We will be justified in focusing our attention on our better sites. An expenditure of $\$ 40.00$ an acre on Site II may be a more profitable investment than $\$ 10.00$ spent on an acre on Site V.

We have tens of thousands of acres of Sites II and III that are covered with hardwoods. Great sweeps of land in the Fraser Valley, for example, are forested with stands of hardwood and maple, and under the hardwood trees are the huge old fir stumps. These are very accessible stands on good ground where the best forest management can be practiced.

Quite probably many of these hardwood stands will become merchantable in the course of time. Indeed, even now there is a limited market for hardwoods.

Many of these hardwood stands have an understory of conifers, and as time goes on they will become converted gradually to softwoods.

Are these hardwood stands just as desirable as softwoods? Let us look at the following aspects of the situation:

\footnotetext{
${ }^{1}$ A paper presented at the Annual Meeting of Canadian Institute of Forestry, October, 1954, at Victoria, British Columbia. Read by Prof. J. W. Ker, Faculty of Forestry, U.B.C.

${ }^{2}$ Chief Forester, Canadian Forest Products Ltd., Vancouver, British Columbia.
} 
1. Our good sites generally will produce up to double the yield in softwoods that they will in hardwoods.

2. Softwood stumpage is worth five to ten times as much as hardwood stumpage, and all visible trends seem to indicate that the value of softwood stumpage will continue to remain well in the lead. Indeed, if we are hoping for greatly increased stumpage returns for hardwoods, we need only take a quick glance at the hardwood timber inventories in eastern Canada and eastern and southern United States. We are in for stiff hardwood competition.

3. A large portion of the hardwood stands are on hillsides or other sites where hardwoods do not attain their optimum development. They are inferior stands which probably never will have a merchantable volume.

In the Southern pine region the timbermen were quite indifferent to their hardwood problem for many years. In the past few years, however, they have recognized hardwoods as being one of their major problems, and they are bending great efforts to bring the pine trees back. We have a similar problem here, though on a much more limited scale. Although the percentage of total forest area covered by hardwoods on the Coast is small, the problem is accentuated by the fact that alder and maple have invaded many of the most productive and the most accessible sites.

There is not too much difference of opinion that we must achieve full stocking of desirable species if we are to increase timber production to a maximum. Cutover lands should be restocked promptly, and the "waiting period" reduced to a minimum. The best sites provide the greatest problem, and at the same time these sites will repay the largest rewards to management.

A wider area of difference of opinion will arise when we approach the problem of increasing the quality of production. This brings up the traditional argument of growing wood versus growing high grade logs. It is a complex problem.

What is the proper rotation for Douglas fir timber on the Coast? I doubt whether anyone knows. The rotation will vary with site, with markets and with accessibility.

I remember seeing a fine stand of spruce in Central Germany that was 145 years old. This stand was being thinned. It was in an area where "small wood" was greatly in demand at profitable prices, and where the stand could have been grown profitably on a much shorter rotation.

I have never ceased to marvel at the vigorous, dynamic character of socalled "old growth" fir stands on the Coast that are between 200 and 300 years of age. Indeed, one occasionally will find a local stand as old as 500 years which is healthy, sound, vigorous, and well stocked. Growth and mortality are practically in balance in these older stands, but if we isolate the plus increment of those trees which do not die, the total current annual growth of high quality wood is impressive.

There are always exceptions where insects or fungi have taken their toll but, in the main, the younger fir stands which have been logged in the past have been sound and thrifty. 
Our hemlock, too, can do very well on long rotations, though not of course on as long a rotation as fir. I consider that the finest hemlock stand I have seen was 180 years of age, and I have seen some splendid 250 year old stands.

From a straight silvicultural point of view our Coast stands appear to be well adapted to long rotations. Are these stands adapted to long rotations from a practical business and economic standpoint, as well? We must give this problem careful study.

We logged a seven-acre, 400-year-old fir stand on Site 175 which produced a yield of $180 \mathrm{MBM}$ per acre. The stumpage realization on this high grade peeler stand was about $\$ 30$ per thousand, so that the stumpage value per acre was $\$ 5,400$.

If interest is excluded, this stand put on $\$ 12.50$ worth of increment per acre annually for 400 years, in terms of 1950 dollars.

I cite this exceptional example of timber yield because it is a concrete example of a "long rotation" harvest that actually has taken place. I cite it, too, just as a hint that 100 years may not be a "long" rotation in fir, that perhaps the rotation, in some cases, might be 150 or 200 years.

I might add, for the benefit of our eastern foresters, that the equivalent cubic volume (net water scale) of this unusual stand was about 320 cords per acre. In comparison, an average Coast stand today yields about 70 to 90 cords to the acre.

An accessible, high site 80 year old second growth fir stand in the Fraser Valley recently was sold for $\$ 12.00$ per MBM stumpage. The stand yielded a cut of 45,000 board feet per acre, so that the total stumpage value was $\$ 540$ per acre.

What was the value of this stand thirty years ago, in the year 1924 ? The stumpage price for good quality second growth at that time was $50 \mathrm{c}$ per MBM.

Back in the year 1924 this stand would have been a merchantable volume of not more than $15 \mathrm{MBM}$ per acre. It would have been low quality timber because of its small size. But if we assume that it was merchantable at that time, and if we allow a stumpage value of 50 cents per MBM, that stand was worth $\$ 7.50$ per acre in that year.

On this basis, then, the stand has increased in value to 72 times its 1924 value. Expressed in another way, the average annual value increment in the past 30 years was $\$ 17.75$ per acre. It might be added that this increase in value took place in spite of a ten year depression in timber values in the intervening period. Even if the depreciation of the dollar is taken into account, the increase in value has been impressive.

We can only guess at the rate at which this stand would have increased in value over the next 30 years, if it had not been cut. We know that the stand would continue to produce a sawtimber yield of about 800 board feet per acre per year. We can be quite sure, too, that in another 30 years there will be a premium market for plywood logs and higher grade sawlogs from 110 year 
old stands, and that there would be available perhaps 100 cords of smallwood per acre, in addition to the sawtimber yield. In that year there probably will be a firm market for smallwood. The present market for smallwood is weak.

If we apply long term stumpage trends, I believe we could say that stumpage values for this stand would be $\$ 25$ per $M B M$, at a very minimum, for sawtimber and $\$ 3.00$ per cord for pulp wood in the year 1984. On this basis the value of the stand would have increased to $\$ 2025$ per acre, or a fourfold increase in the next thirty years. Perhaps the increase in value might be much greater than this. If there is inflation, it is quite likely that second growth timber will continue to be a good hedge, as it has been in the past.

Whether any future increase in value will be sufficient to cover taxation and management costs is, of course, open to debate. The studies of W. E. Bond and R. R. Reynolds in the Southern Pine Region over the past 15 to 20 years have built up a strong body of evidence in favor of growing higher quality wood, through longer rotations and through effective thinnings. Even though Southern pine stands will yield profitable returns on short rotations, these investigators have demonstrated by numerous practical examples that their stands will yield greater annual returns by producing a diversity of products on longer rotations.

Longer rotations will not be feasible if value increment is taxed away by over-zealous assessors. If the tax authority wishes the tax base to remain productive, it must not "kill the goose that lays the golden egg". If the assessor applies adequate discount factors to cover market risk, management costs and interest, he will encourage the building up of growing stock and the lengthening of rotations. The net result will be a healthier forest economy and an assured source of future taxation. reasons:

Longer rotations do not necessarily mean more infrequent cuts for two

1. If the management plan is properly organized, the volume and frequency of annual cuts on long rotations are about the same as on short rotations. We can produce the same volume of wood per year by clear cutting 1000 acres a year on a 100 year rotation as by cutting twice the area (2000 acres) annually on a fifty year rotation.

2. Long rotations are going to be well adapted to periodic thinnings. Thinnings can have the effect of increasing the number and frequency of cuts on the same area, as compared with short rotation management.

The Forest Service inventory shows that we still have a huge volume of old growth timber on the Coast. At the same time, we have quite limited areas of older second growth timber. If we are to harness the productive capacity of all our forest land, the old growth timber must be harvested. If possible, the rate of old growth harvesting must be accelerated. This is our most pressing task.

At the same time, we can allow our second growth stands to grow up to a good size, and so build up our growing stock to the place where we can practice second growth management. To commence clear cutting our young second growth stands today under a policy of "short rotation forestry" would, in my opinion, be unwise management. 
We do not yet have much experience in thinnings. The excellent start that has been made by such men as Chris Joergensen, Norman Worthington, Geoff Marples and others have demonstrated that we can make profitable, economic thinnings in older second growth stands.

Whether we should thin from above or from below, or just what middle ground will be most satisfactory we cannot say. We must try all sorts of thinnings and keep good records of the results.

At the risk of speaking out in advance of established thinning practice $\mathbf{I}$ would like to say a few words in favor of retaining a fair proportion of high quality trees for the final crop. A moment ago I described the rapid increase in value of an 80 year old fir stand in the Fraser Valley. I would like to suggest that the rate of value increase in this stand can be compounded by effective thinning practice.

There will always be pressure to "high grade" on a thinning basis, just as high grading can be carried out by clear cutting on too short a rotation.

Our preliminary experience shows that we may have difficulty thinning hemlock stands, because of the susceptibility of these stands to blowdown and decay. Still, there are some good arguments for long rotations in some hemlock stands. Mean annual increment in hemlock stands is well sustained on long rotations, and there are the traditional advantages of lower costs and higher values that go with harvesting older stands.

Some of our hemlock sites are in areas where road construction and road maintenance costs are high. Under a long rotation plan, main roads might be kept in service, while spur roads are allowed to wash away, to be rebuilt when the area is logged again in another hundred years.

Those who argue that future markets will not require high quality wood, that technological changes will obliterate the premium now paid for higher grade logs, can develop a good case.

On the other hand, there are even stronger developments working toward a sustained premium for good logs.

Here on the West Coast the trend is toward more careful sorting of logs and toward a higher premium for good logs. This trend is taking place in spite of the fact that our pulp industry is expanding rapidly.

Recent surveys of the timber supply situation in the United States indicate that while there is no apparent shortage of wood fibre, definite pressure is being exerted on the available supplies of sawtimber.

In Sweden's highly developed forest economy the sawmills are able to bid successfully against the pulp mills for high quality logs in large volume.

The plywood industry has been expanding at a rapid rate. Plywood plants generally require higher grade logs.

One of the most effective arguments in favor of larger logs is that they cost less to produce and to manufacture than do small logs. Norman Worthington and Elmer Shaw in a study published in the Timberman in August 1952, 
showed that it cost $\$ 10.96$ per hundred cubic feet to deliver a 14 -inch second growth $\log$ to a mill, whereas the cost for an 8-inch log was $\$ 21.27$.

Mr. Arthur Hart of the U.S. Forest Service found that the most important factor affecting the costs of producing pulpwood in the Northeast is tree size. He reported in the Journal of Forestry that a cord of 18-inch d.b.h. spruce trees could be converted into pulpwood and delivered to the mill for 3.57 man hours of labor, whereas 8-inch d.b.h. trees required 4.93 man hours of labor.

It is perhaps axiomatic that as the piece average goes up the costs go down, if other conditions remain the same. Still, we can do a lot to bring down the costs of producing small wood.

The market for small wood is bound to strengthen in the future, and this will fit in perfectly with large log management. The smaller trees, the defective trees and the tops can be converted into pulp, while the higher grade trees will be converted into lumber, timbers, plywood and piling.

If the pulp mills fifty years hence can outbid the plywood mills for good logs, we need not despair that large log management was a mistake. Indeed, if the pulp industry is that prosperous, the timber manager will have good cause to rejoice. He may make a higher profit selling large logs to the pulp mill than selling small logs. Indeed, on today's pulp log market the old growth hemlock $\log$ generally returns a better profit to the logger than does the small log.

The timber management policy of the Crown Zellerbach Corporation at its U.S. Tree Farms is geared to the production of maximum wood values. Although the Company's raw material needs are for pulp and paper, it gears forest management to maximum growth of highest value wood rather than for straight pulpwood. This progressive Company is setting a pattern of management that deserves careful study by all of us.

By achieving full production on good sites, by extending the length of rotation where possible, and by thinning with future values in mind, we will increase the quantity and quality of timber production.

These are sound business objectives.

\section{DISCUSSION}

Improving the Quality and Quantity of Production Panel by F. L. Flatt and T. G. Wright

\section{A. P. MacBean, Chairman}

Tom Wright noted in his paper that "we still have a huge volume of old growth timber on the Coast".

The Surveys Division of the B.C. Forest Service advises that its most recent estimate is 54.7 billion c.f. which would be approximately 328.6 billion f.b.m. At the 1953 rate of cutting, 617 million c.f. or 3.7 billion f.b.m., this mature inventory will last 88.7 years.

In advocating long rotations, Wright referred to studies in the Southern Pine Regions which indicated greater returns through longer rotations. MacBean noted that a forester who is with a pulp and paper company in the 